\title{
Advances in Biological Psychiatry
}

Vol. 19

\author{
Series Editors D. Ebert, Freiburg \\ K.P. Ebmeier, Edinburgh \\ W.P. Kaschka, Ulm \\ Th. Rechlin, Weinsberg
}

KARGER $\begin{aligned} & \text { Basel· Freiburg } \cdot \text { Paris } \cdot \text { London } \cdot \text { New York } \cdot \\ & \text { Nelhi } \cdot \text { Bangkok } \text { Singapore } \cdot \text { Tokyo } \cdot \text { Sydney }\end{aligned}$ 


\title{
New Models for Depression
}

\author{
Volume Editors $\quad$ D. Ebert, Freiburg \\ K.P. Ebmeier, Edinburgh
}

21 figures, 1 in color, and 3 tables, 1998

KARGER $\begin{aligned} & \text { Basel·Freiburg } \cdot \text { Paris } \cdot \text { London } \cdot \text { New York } \\ & \text { New Delhi } \cdot \text { Bangkok } \cdot \text { Singapore } \cdot \text { Tokyo } \cdot \text { Sydney }\end{aligned}$ 


\section{- \\ Dieter Ebert}

Department of Psychiatry

University of Freiburg

Hauptstrasse 5

79104 Freiburg (Germany)

\section{Klaus P. Ebmeier}

MRC Brain Metabolism Unit and

Department of Psychiatry, University of Edinburgh Royal Edinburgh Hospital

Morningside Park

Edinburgh EH10 5HF (UK)

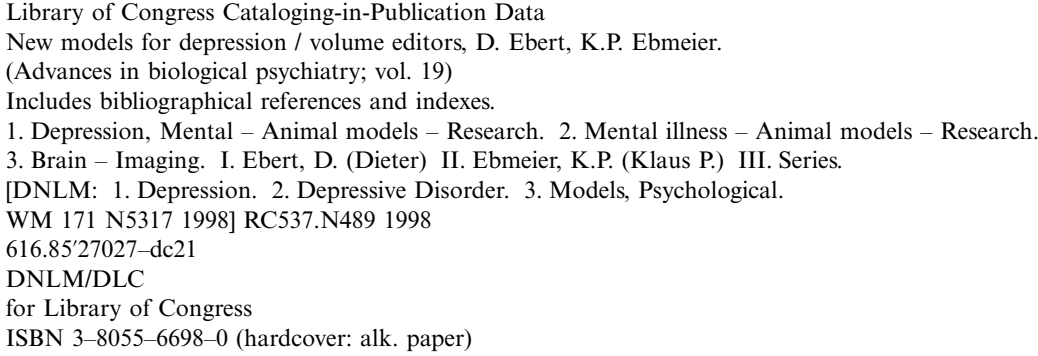

Drug Dosage. The authors and the publisher have exerted every effort to ensure that drug selection and dosage set forth in this text are in accord with current recommendations and practice at the time of publication. However, in view of ongoing research, changes in government regulations, and the constant flow of information relating to drug therapy and drug reactions, the reader is urged to check the package insert for each drug for any change in indications and dosage and for added warnings and precautions. This is particularly important when the recommended agent is a new and/or infrequently employed drug.

All rights reserved. No part of this publication may be translated into other languages, reproduced or utilized in any form or by any means electronic or mechanical, including photocopying, recording, microcopying, or by any information storage and retrieval system, without permission in writing from the publisher.

C) Copyright 1998 by S. Karger AG, P.O. Box, CH-4009 Basel (Switzerland)

Printed in Switzerland on acid-free paper by Reinhardt Druck, Basel

ISBN 3-8055-6698-0 


\section{Contents}

VII Preface

1 Cognitive Impairment in Depression: Psychological Models and Clinical Issues

Murphy, F.C.; Sahakian, B.J. (Cambridge); O’Carroll, R.E. (Stirling)

34 Neurobehavioural Substrates of Mood Induction Schneider, F.; Weiss, U. (Düsseldorf)

49 Animal Models for Depression: The Anhedonic Rat - Theory and Practice

Matthews, K.; Reid, I. (Dundee)

72 The Medial Prefrontal Cortex in Depression Elliott, R.; Dolan, R.J. (London)

94 Transcranial Magnetic Stimulation: A New Method for Investigating the Neuroanatomy of Depression George, M.S.; Nahas, Z.; Speer, A.M. (Charleston, S.C.); Kimbrell, T.A.; Wassermann, E.M. (Bethesda, Md.); Teneback, C.C.; Molloy, M.; Bohning, D.; Risch, S.C. (Charleston, S.C.); Post, R.M. (Bethesda, Md.)

123 Neurological Models of Depression Starkstein, S.E. (Buenos Aires) 
136 Structural and Functional Brain Markers of Age of Onset and Chronicity in Major Depressive Disorder

Shah, P.; Ebmeier, K.P. (Edinburgh)

153 Sleep Deprivation and Dopamine: The Psychostimulant Theory of Antidepressant Sleep Deprivation

Ebert, D. (Freiburg)

170 The Pathophysiology of Depression: A Synthesis of the Role of Serotonin and Corticosteroids

McAllister-Williams, R.H.; Young, A.H. (Newcastle upon Tyne)

199 Author Index

200 Subject Index 


\section{............................. \\ Preface}

The way we approach depression scientifically depends on our theoretical framework for depression and its aetiology, and on the tools at our disposal to investigate brain function. This means that models of depression will change with time. They have evolved particularly fast within the last few years, with the development of new imaging tools, such as functional MRI and TMS which are combined with the clinical method and experimental approaches to symptoms. This book brings together recent updates on the main themes of depression research, presented by active researchers in the field. Five of the chapters deal directly with brain imaging methods, either examining brain structure (Starkstein; Shah and Ebmeier), brain function (Schneider and Weiss; Elliott and Dolan; George), or functional neurochemistry (Ebert). A second topic, summarised by Murphy et al., is the renaissance of psychological approaches, both in terms of a neuropsychology of depression and as effective psychotherapy as an important adjunct to pharmacotherapy. Neurochemical models have a long pedigree in depressive illness. The recent years have seen a change from one-neurotransmitter explanations to delineating complex relationships and interactions. McAllister-Williams and Young explore one such interaction, that between stress hormones and serotonin. Finally, the behavioural animal models, described by Matthews and Reid, play an important part both in the scientific exploration of mechanisms involved in depression and in the development of effective treatments.

The limbic system, including the paralimbic cortex, has long been implicated in depression, but only recently has a convergence of evidence started to provide direct scientific support for this brain-behaviour relationship. Judging from the assembled results, the next decade promises to be exciting for depression research! 